\title{
Impaired expression of protein phosphatase 2A subunits enhances metastatic potential of human prostate cancer cells through activation of AKT pathway
}

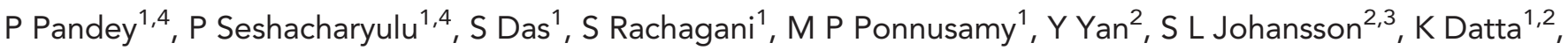 \\ M Fong Lin ${ }^{1,2}$ and S K Batra*,1,2 \\ ${ }^{1}$ Department of Biochemistry and Molecular Biology, University of Nebraska Medical Center, Omaha, NE 68198-5870, USA; \\ ${ }^{2}$ Eppley Institute for Research in Cancer and Allied Diseases, University of Nebraska Medical Center, Omaha, NE, USA and \\ ${ }^{3}$ Department of Pathology and Microbiology, College of Medicine, University of Nebraska Medical Center, Omaha, NE, USA
}

Background: Protein phosphatase 2A (PP2A) is a dephosphorylating enzyme, loss of which can contribute to prostate cancer (PCa) pathogenesis. The aim of this study was to analyse the transcriptional and translational expression patterns of individual subunits of the PP2A holoenzyme during PCa progression.

Methods: Immunohistochemistry (IHC), western blot, and real-time PCR was performed on androgen-dependent (AD) and androgen-independent (Al) PCa cells, and benign and malignant prostate tissues for all the three PP2A (scaffold, regulatory, and catalytic) subunits. Mechanistic and functional studies were performed using various biochemical and cellular techniques.

Results: Through immunohistochemical analysis we observed significantly reduced levels of PP2A-A and - $B^{\prime} \gamma$ subunits $(P<0.001$ and $P=0.0002$ ) in PCa specimens compared with benign prostate. Contemporarily, there was no significant difference in PP2A-C subunit expression between benign and malignant tissues. Similar to the expression pattern observed in tissues, the endogenous levels of PP2A-A and $B^{\prime} \gamma$ subunits were abrogated from the low metastatic to high metastatic and AD to Al cell line models, without any change in the catalytic subunit expression. Furthermore, using in vitro studies we demonstrated that PP2A-A $\alpha$ scaffold subunit has a role in dampening AKT, $\beta$-catenin, and FAK (focal adhesion kinase) signalling.

Conclusion: We conclude that loss of expression of scaffold and regulatory subunits of PP2A is responsible for its altered function during PCa pathogenesis.

Prostate cancer (PCa) is the second leading cause of cancer-related death among men in United States after lung cancer. In 2012, the estimated number of new cases and deaths caused by PCa are 241740 and 28170 , respectively (Siegel et al, 2012). A majority of PCa patients are older men (over 65 years) and the disease is rarely seen in younger men (below 40 years) (Hankey et al, 1999). The median age for PCa diagnosis and death is 67 and 81 years, respectively (Hoffman, 2011). The growth of $\mathrm{PCa}$ remains androgen-dependent $(\mathrm{AD})$ in its initial stage. Hence, during the $\mathrm{AD}$ state, androgen deprivation therapy (ADT) leads to regression of the locally advanced PCa (Chuu et al, 2011). When PCa relapses after $\mathrm{ADT}$, the disease progresses to an androgen-independent (AI) state and eventually hormone-refractory disease develops (Sharifi et al, 2005), which does not effectively respond to the existing

\footnotetext{
*Correspondence: Dr SK Batra; E-mail: sbatra@unmc.edu
}

${ }^{4}$ These authors contributed equally to this work.

Received 7 February 2013; revised 18 March 2013; accepted 22 March 2013; published online 18 April 2013 
therapeutic strategies. Many oncogenes and tumour suppressor genes have been thoroughly investigated and they provide credence to the idea that alteration of their normal physiological actions and regulations can have an adverse impact on gene expression, resulting in various diseases including cancer. Genome-wide expression profiling and pathway prediction associates a number of up- and downregulated genes with cancer progression. Many candidate tumour suppressor genes like $R b, p 53, P T E N, C D K N 2 A, T P 73$, ICAM1, SOCS1/2, SPRY2, PPP2CA, and PPP3CA have been shown to be downregulated in cancer, whereas many proto-oncogenes such as AKT, PKC, mTOR, c-fos, c-jun, HGF, KRAS, MET, and EGFR have been shown to be upregulated (Singh et al, 2008).

Uncontrolled cell growth, metabolism, proliferation, migration, and motility of cancer cells are regulated by various kinases and phosphatases (Cohen, 2001). Protein phosphatase 2A (PP2A) is highly conserved across a variety of eukaryotic species and accounts for as much as $1 \%$ of the total cellular protein (Wera and Hemmings, 1995). Protein phosphatase 2A is one of the major serine threonine phosphatases and structurally it is composed of three subunits: catalytic (C), scaffold (A), and regulatory (B) subunit, with functional variability (Zhang and Claret, 2012). Protein phosphatase 2A exists in two different forms: core enzyme and holoenzyme (Kremmer et al, 1997). The core enzyme is composed of the scaffold subunit (PP2A-A) and the catalytic subunit (PP2A-C) and is present in the heterodimeric form. The spatial and temporal diversity of this enzyme is provided by the regulatory subunit (Virshup and Shenolikar, 2009) and it interacts with the heterodimeric core enzyme to form the heterotrimeric holoenzyme. The PP2A holoenzyme exists in soluble form and gets compartmentalised in the cytosol, nucleus, mitochondria, cytoskeleton, and organelle membranes (Inagaki et al, 1994). Both the PP2A scaffold and the catalytic subunit exist in two different isoforms $\alpha$ and $\beta$, among which $\alpha$ form is predominant in nature. The regulation of PP2A activity mainly relies on the regulatory $\mathrm{B}$ subunit, which determines substrate selectivity, subcellular localisation, and regulates the catalytic activity in a wide range of biological processes (Yang et al, 2003; Yang and Phiel, 2010). The regulatory subunit is complex and diverse in nature and constitutes four different families: B (B55/ PR55), B' (B56/PR61), B" (PR48/PR72/PR130), and B" ${ }^{\prime \prime \prime}$ (PR93/ PR110). To provide further complexity, each member of the regulatory subunit is subdivided into various isoforms like $\alpha, \beta, \gamma$, $\delta$, and $\varepsilon$ (Kamibayashi et al, 1994; Shi, 2009).

Chen et al (2004) have demonstrated that suppression of a specific regulatory subunit $\mathrm{PP} 2 \mathrm{~A}-\mathrm{B}^{\prime} \gamma$ is sufficient for human cellular transformation by displacing $\mathrm{PP} 2 \mathrm{~A}-\mathrm{B}^{\prime} \gamma$ from the $\mathrm{AC}$ dimer altering the PP2A-specific phosphatase activity in human embryonic kidney epithelial cells (Chen et al, 2004). Somatic alterations of $\mathrm{PP} 2 \mathrm{~A}-\mathrm{A} \alpha, \mathrm{A} \beta$, and $\mathrm{B}^{\prime} \gamma$ are associated with breast, lung and colorectal cancer, and soft tissue sarcomas (Wang et al, 1998; Ruediger et al, 2001; Esplin et al, 2006; Perrotti and Neviani, 2008; Grochola et al, 2009). Functional haploinsufficiency of PP2A-A $\alpha$ or loss of PP2A-A $\alpha$ are defective in binding with $\mathrm{B}^{\prime} \gamma$, resulting in complete loss of hetrotrimeric complex formation, eventually leading to cellular transformation (Chen et al, 2005), thus supporting the tumour suppressor nature of PP2A (Mumby, 2007). In addition, earlier reports of Cho et al (2007) and Xu et al (2006) have explained about the holoenzyme interaction of PP2A$\mathrm{A} / \mathrm{PP} 2 \mathrm{~A}-\mathrm{C}$ with the specific regulatory B subunit B56\%. Protein phosphatase type $2 \mathrm{~A}$ has an important role in DNA replication, cell cycle, signal transduction, and cytoskeleton dynamics (Janssens and Goris, 2001). It positively regulates apoptosis and negatively regulates the mitogenic pathway, suggesting that loss of it might be involved in cancer development and progression (Perrotti and Neviani, 2008). In various malignancies, such as lung, breast, colon, gastric, and leukaemia, it has been shown that PP2A is downregulated and its role in transformation clearly defines PP2A as a tumour suppressor gene (Westermarck and Hahn, 2008). In prostate epithelia, various growth factors, receptors, and androgens coordinately regulate cell proliferation by altering the equilibrium between phosphorylation and dephosphorylation. Studies have shown that the post-translational modifications of the androgen receptor, such as active phosphorylation, facilitates androgen-binding capacity and aids in the activation of the DNAbinding domain during transformation (Brinkmann, 2001). Previous studies have shown that the androgen receptor is regulated by phosphorylation and dephosphorylation. Insufficient dephosphorylation of the androgen receptor leads to continuous activation of the androgen receptor and enhances the androgen receptor-mediated signalling pathways.

The aim of this study was to elucidate the expression pattern at transcriptional and translational level of the scaffold, catalytic and regulatory subunits of $\mathrm{PP} 2 \mathrm{~A}$ in $\mathrm{AD}$ and $\mathrm{AI}$ PCa cells, and in benign and cancerous tissues. The methods in this study included immunohistochemical analysis, quantitative real-time PCR, and western blot assay to investigate the expression pattern of PP2A subunits in PCa progression. Furthermore, we extended our study by knocking down of PP2A scaffold subunit to identify whether the loss of PP2A scaffold subunit expression may be one of the mechanisms contributing to PCa progression. Overall, our results suggest that even if there is no significant change in the expression level of the catalytic subunit of PP2A, the differential expression or loss of expression of the scaffold and regulatory subunits may lead to altered function during the pathogenesis of PCa.

\section{MATERIALS AND METHODS}

Cell culture. Human PCa cell lines were obtained from various sources: LNCaP cells having passage number less than 33 were designated as clone 33 (C-33), which are generally $\mathrm{AD}$ cells, and more than 80 passaged cells were designated as clone 81 (C-81, AI) (Igawa et al, 2002; Singh et al, 2008), PC-3 (low metastatic, AI) cells were obtained from the American Type Culture Collection (Manassas, VA, USA) and PC-3M (AI), a highly metastatic subline derived from liver metastasis of PC-3 cells, was obtained from Dr Fidler University of Texas MD Anderson Cancer Center, Houston, TX, USA. (Stephenson et al, 1992). PC-3 and PC-3M cell lines were maintained in RPMI 1640 culture medium containing $10 \%$ fetal bovine serum (FBS) and antibiotics $\left(100 \mu \mathrm{g} \mathrm{ml}^{-1}\right.$ penicillin and streptomycin) and LNCaP C-33 and C-81 cells were grown in RPMI 1640 culture medium supplemented with $5 \%$ FBS and antibiotics (penicillin and streptomycin $100 \mu \mathrm{g} \mathrm{ml}^{-1}$ ). All cell lines were grown at $37^{\circ} \mathrm{C}$ with $5 \% \mathrm{CO}_{2}$ in a humidified atmosphere and media were changed every other day.

Antibodies and transfection reagents. The antibodies used are very specific for three different subunits. Protein phosphatase $2 \mathrm{~A}$ catalytic subunit (catalogue no. 1512-s; Epitomic, Burlingame, CA, USA) reacts to both $\alpha$ - and $\beta$-isoform of catalytic subunit. The antibody does not crossreact among other family members of PP2A subunits. Antibody directed against PP2A-A scaffold subunit (81G5 rabbit monoclonal antibody, catalogue no. 2041-s; Cell Signalling Technology, Danvers, MA, USA) detects both $\alpha$ - and $\beta$-isoform of PP2A scaffold subunit. Protein phosphatase type $2 \mathrm{~A}-\mathrm{B} 56-\gamma$ antibody (H-40, rabbit polyclonal, catalogue no. SC67038; Santa Cruz Biotechnology, Santa Cruz, CA, USA) recognises the epitope corresponding to amino acids 431-470 near the $\mathrm{C}$ terminus of PP2A-B56- $\gamma$. Other antibodies used for signalling studies include: phospho-AKT, total AKT, active $\beta$-catenin, phospho-FAK (focal adhesion kinase) (Y576/577), total FAK, and $\beta$-actin (obtained from Cell Signalling). Horseradish peroxidase-coupled anti-mouse and anti-rabbit IgG secondary antibodies, and enhanced chemiluminescence reagent was 
purchased from Amersham Biosciences (Buckinghamshire, UK). Transient transfection was performed using Lipofectamine 2000 reagent (Invitrogen, Carlsbad, CA, USA). Two small-interfering RNA (siRNA) oligos targeted against human PP2A-A $\alpha$ (PPP2R1A), NM 014225 (Si-1 ' 5 '-AGGCGGAACUUCGACAG UA- 3 ' ' and $\mathrm{Si}-2$ ' 5 '-AAACUUAACUCCUUGUGCA-3') and scramble (SCR) oligo were purchased from Thermo Scientific Dharmacon (Lafayette, CO, USA) and were used for the transient knockdown study.

Immunohistochemistry analysis. Prostate tissue array having normal prostate tissues and multiple PCa (Gleason grade 6-10) tissue spots were obtained from Biomax (Bethesda, MD, USA). First, the paraffin-embedded TMA arrays were deparaffinised in xylene for $4 \times 10 \mathrm{~min}$, each followed by rehydration through graded ethanol. Endogenous peroxidase was blocked using 3\% hydrogen peroxide for $30 \mathrm{~min}$. Antigen retrieval was accomplished using $0.01 \mathrm{M}$ preheated citrate buffer $\left(\mathrm{pH}-6.0,90^{\circ} \mathrm{C}\right.$ ) for $15 \mathrm{~min}$ and was allowed to cool at room temperature. The slides were then washed with phosphate-buffered saline (PBS) $2 \times 5$ min each. Binding of nonspecific proteins were blocked by incubating the tissue slides with $2.5 \mathrm{U}$ horse serum (ImmPRESS kit; Vector Labs, Burlingame, CA, USA) for $2 \mathrm{~h}$. The sections were incubated overnight at $4{ }^{\circ} \mathrm{C}$ with primary antibodies, PP2A-C (1:500), PP2A$\mathrm{A} \alpha / \beta(1: 50)$, and PP2A- $\mathrm{B}^{\prime} \gamma(1: 75)$ diluted in PBS. Slides were then washed with PBS $4 \times 10$ min and incubated with the appropriate secondary antibody (peroxidase-labelled, universal anti-mouse/ anti-rabbit IgG ImmPRESS kit; Vector Labs) for $1 \mathrm{~h}$ at room temperature. The slides were then washed using PBS $4 \times 10 \mathrm{~min}$ and the tissue sections were treated with $\mathrm{DAB}$ reagent to develop colour as per the manufacturer's instruction (DAB substrate kit; Vector Labs) and the sections were counterstained with haematoxylin (Vectors Lab). Finally, the slides were washed in tap water and were dehydrated in increasing grades of alcohol (20-100\%), and then washed with xylene for $5 \mathrm{~min}$ and dried at $37^{\circ} \mathrm{C}$. After air drying, slides were mounted in paramount mounting medium (Fisher Scientific, Fair Lawn, NJ, USA). Slides were observed and photographs were taken using Nikon Eclipse E400 light microscope (Kawasaki, Japan).

Immunohistochemistry scoring. Stained tissue arrays were observed and graded by pathologist Dr Sonny L Johansson at UNMC (Omaha, NE, USA). The grading of PP2A-A-, $-\mathrm{B}^{\prime} \gamma-$, and -C-stained intensity was scored on a $0-3+$ scale and defined as follows: 0 , no staining; $1+$, weakly positive; $2+$, moderately positive; and $3+$, strongly positive. The percentage of the area stained was based on: $0-25 \%=1,26-50 \%=2,51-75 \%=3$, and $76-100 \%=4$. The composite score is the product of the percentage of positive cells per area and intensity of staining. The composite score is used to define the positivity and negativity of staining. A composite score of 0 is considered negative staining, whereas $\geqslant 1$ is positive staining. Photographs of the representative area were taken.
RNA isolation and quantitative real-time PCR. Total RNA was isolated using the Qiagen RNeasy mini kit (Qiagen, Valenica, CA, USA). The concentration of RNA was determined using NanoDrop ND 1000 Spectrophotometer (Wilmington,DE,USA) and cDNA was synthesised by reverse transcription as described previously (Moniaux et al, 2008). Quantitative reverse transcription real-time PCR was carried out as described previously (Rachagani et al, 2011). Real-time PCR assay was performed on Roche Light Cycler 480 systems (Roche, Indianapolis, IN, USA). The primer sequences were designed using the Primer 3 software (Rozen and Skaletsky, 2000) and the sequences are given in Table 1. Polymerase chain reaction was then performed in $10 \mu \mathrm{l}$ reaction containing $5 \mu \mathrm{l} 2 \times$ SBYR Green Master Mix, $3.2 \mu \mathrm{l}$ of autoclaved nuclease free water, $1 \mu \mathrm{l}$ diluted RT product $(1: 10)$, and $0.2 \mu \mathrm{l}$ each of forward and reverse primers $(5 \mathrm{pmol})$ for all three subunits. The amplification conditions used for all three subunits were a two-step cyclic process $\left(95^{\circ} \mathrm{C}\right.$ for $10 \mathrm{~min}$, followed by 45 cycles for $95^{\circ} \mathrm{C}$ for $10 \mathrm{~s}, 60^{\circ} \mathrm{C}$ for $10 \mathrm{~s}$, and $72^{\circ} \mathrm{C}$ for $10 \mathrm{~s}$ ). The real-time PCR reactions were performed in triplicate and template controls were run for each assay under similar conditions. $\beta$-Actin was used as an internal control. The fold change of PP2A$A,-B^{\prime} \gamma$, and $-C$ was calculated by Delta Delta CT method.

Protein isolation and western blot assay. Cells were washed two times with PBS and lysed in RIPA buffer (Tris- $\mathrm{HCl} 0.25 \mathrm{M}$, SDS $0.2 \%, \mathrm{pH} 6.8$, glycerol $20 \%, 1 \mathrm{~mm} \mathrm{NaF}, 10 \mathrm{~mm} \beta$-glycerol phosphate, and $1 \mu \mathrm{ml}^{-1}$ protease inhibitor cock tail; SigmaAldrich Corp., St. Louis, MO, USA). Scraped lysate was passed through a $25-\mathrm{G} 7 / 8$ needle and centrifuged at $4{ }^{\circ} \mathrm{C}$ for $25 \mathrm{~min}$ at 13000 r.p.m. The protein concentration of each sample was quantified by using the Bio-Rad DC Protein Assay kit (Bio-Rad Laboratories, Hercules, CA, USA). Total proteins $(40 \mu \mathrm{g})$ were separated by $10 \%$ SDS-PAGE and transferred to polyvinylidene difluoride (PVDF) membranes. Blocking was performed in 5\% dry milk in PBS for $2 \mathrm{~h}$, and incubated with primary antibodies (at $1: 1000$ dilution) against PP2A-A, PP2A- $\mathrm{B}^{\prime} \gamma$, and PP2A-C) overnight, and then washed with PBST $4 \times 10 \mathrm{~min}$. The corresponding secondary antibodies (at $1: 2000$ dilution) were added and incubated at room temperature for $1 \mathrm{~h}$. After washing with PBST $4 \times 10 \mathrm{~min}$, the signals were detected using enhanced chemiluminence (ECL) reagents and membranes were exposed to ECL-sensitive X-ray films (Molecular Technologies, St.Louis, MI, USA).

Transfection of PCa cells with siRNA specific for PP2A-A $\alpha$. For transient knockdown of PC-3, C-33 and C-81 PCa cells, we used $100 \mathrm{bp}$ of siRNA oligonucleotides of human PP2A-A $\alpha$-specific siRNA and SCR oligos using Lipofectamine 2000 transfection reagent. Cells that have been transfected for $72 \mathrm{~h}$ were considered for experimental studies such as migration assay and immunoblotting analysis. To demonstrate the effect of PP2A-A $\alpha$ knockdown on AKT phosphorylation, whole-cell lysates were collected for further analysis after $72 \mathrm{~h}$ of transfection and proteins were fractionated on 10\% SDS-PAGE and blotted on PVDF membranes. Following blotting, membranes were probed with antibodies specific for PP2A-A $\alpha$, phospho-AKT, total AKT, active

Table 1. The oligonucleotide primers sequence used for detecting the expression of PP2A-C, $-B^{\prime} \gamma$, and $-A \alpha / \beta$, in the RT-PCR analysis

\begin{tabular}{|l|l|c|c|}
\hline Gene & Primer sequences & $\begin{array}{c}\text { Amplified } \\
\text { length (bp) }\end{array}$ & $\begin{array}{c}\text { Annealing } \\
\text { temperature ('C) }\end{array}$ \\
\hline PP2A-C & Forward: 5'-TCGTTGTGGTAACCAAGCTG-3' Reverse: 5'-AACATGTGGCTCGCCTCTAC-3' & 100 & 58 \\
\hline PP2A-B' $\gamma$ & Forward: 5'-ACAGTGAAGGACGAGGCTCA-3' Reverse: 5'-CTTCCAAGGCTTTCTTGGTG-3' & 112 & 54 \\
\hline PP2A-A $\alpha / \beta$ & Forward: 5'-GCTTCAATGTGGCCAAGTCT-3' Reverse: 5'-GGTCCTGGGTCAGCTTCTCT-3' & 102 \\
\hline Abbreviations: PP2A $=$ protein phosphatase 2A; RT-PCR = Real Time -polymerase chain reaction. \\
\hline
\end{tabular}


$\beta$-catenin, phospho-FAK (Y576/577), and total FAK. The blots were re-probed with $\beta$-actin antibody to confirm equal loading of the samples in all the lanes.

\section{Cell migration assays}

Transwell migration and wound healing assay. Assays were adapted with slight modification as described previously (Senapati et al, 2010). For both procedures, PP2A-A $\alpha$ knockdown PC-3 were trypsinised and used to perform assays. First, to investigate the role of PP2A-A $\alpha$ in cell migration, we used Boyden chambers with $8-\mu \mathrm{m}$ pore size. Transient knockdown of PC-3 cells were seeded at the density of $1 \times 10^{5}$ cells per well in the upper chamber of the insert, while the lower chamber was filled with $10 \%$ FBS, which is used as a chemoattractant. After $24 \mathrm{~h}$ of incubation, the PC-3 cells remaining above the insert membrane were removed by gentle scraping with a sterile cotton swab. Cells that invaded through the pores to the bottom of the insert were fixed and stained with crystal violet for $10 \mathrm{~min}$. Invading cells on representative sections of each membrane were counted under light microscopy. Under each experimental condition, the number of invading cells was calculated as the percentage of invaded cells compared with the SCR control cells. The experiment was performed in triplicate and $t$-tests were used to determine the statistical significance in migration between the SCR and knockdown cells. For wound healing assay, post-transfected PC-3 cells were trypsinised, counted, and seeded at a density of $1 \times 10^{5}$ cells in 60 -mm Petri dishes with $10 \%$ RPMI, with and without knockdown of PP2A-A $\alpha$, for $48 \mathrm{~h}$. After overnight incubation and with $>90 \%$ confluence, a wound was induced with a sterile pipette tip. Images of wound areas were randomly chosen and images were obtained at 0 and $12 \mathrm{~h}$, and the motility of the cells was compared between the SCR and knockdown cells.

\section{RESULTS}

Immunostaining of the scaffold subunit of PP2A-A $\alpha / \beta$ in benign and PCa tissues. The expression pattern of the PP2A-A $\alpha$ / $\beta$ scaffold subunit in $\mathrm{PCa}$ and benign tissues was studied using IHC. A total of 175 tissue spots were stained for PP2A-A $\alpha / \beta$, among which $29(n=29)$ were benign and $146(n=146)$ were cancer tissue spots. In benign prostate tissue, a strong expression of $\mathrm{PP} 2 \mathrm{~A}-\mathrm{A} \alpha / \beta$ in the epithelial cells was observed, while no staining was observed in the surrounding stroma (Figure 1A). Out of the 146 total cancer tissues analysed, $12.3 \%$ (18 out of 146) were positive for PP2A-A $\alpha / \beta$. In the benign tissue, $48.2 \%$ (14 out of 29 ) were positive (Table 2). Protein phosphatase type $2 \mathrm{~A}-\mathrm{A} \alpha / \beta$ exhibited both cytoplasmic and nuclear staining patterns and immunohistological staining was stronger in benign tissues compared with malignant tissues and the difference was

A
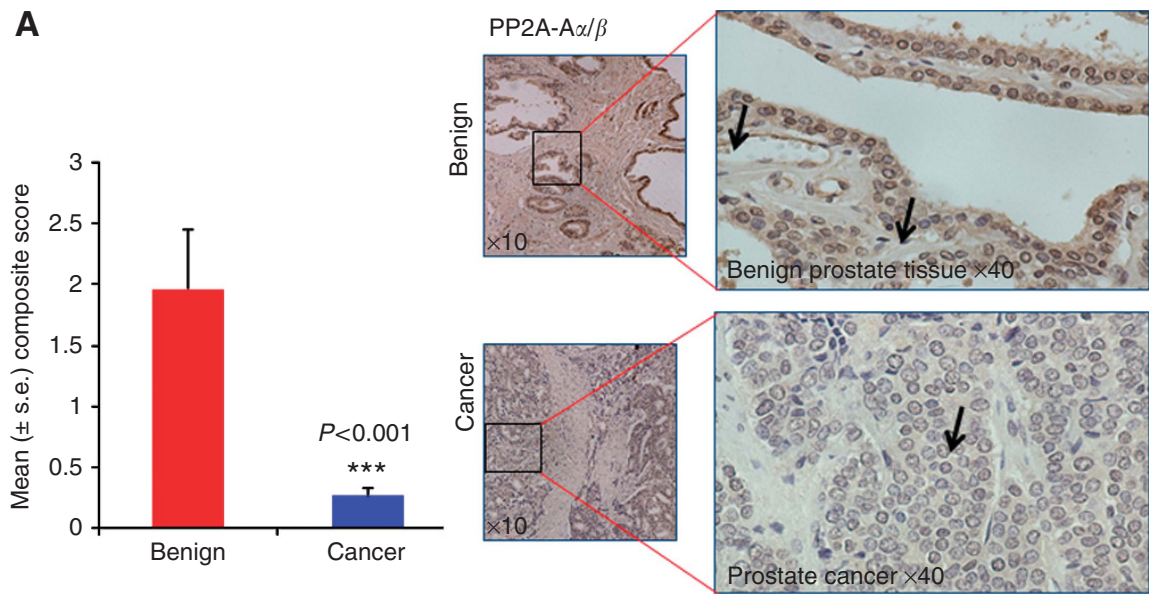

B
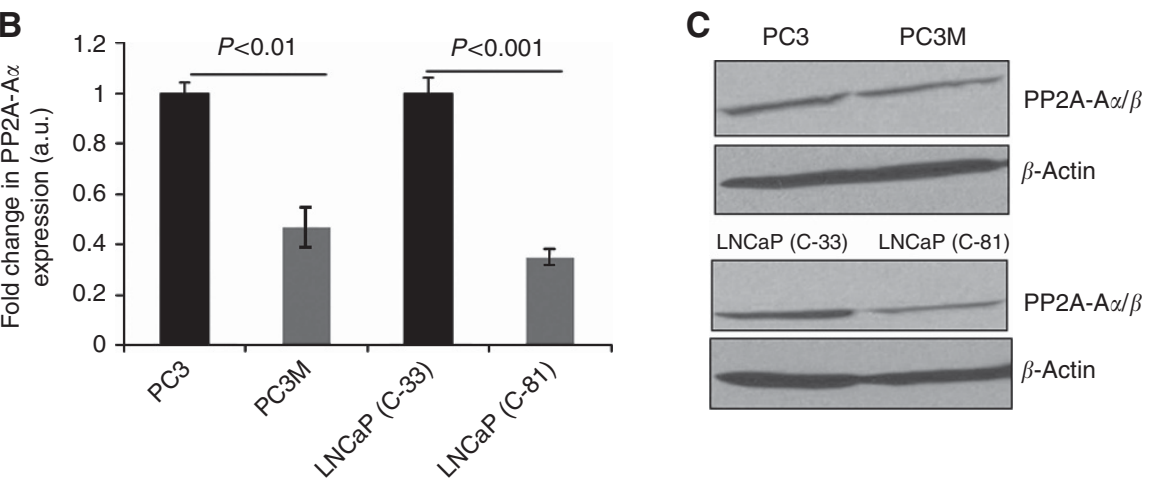

Figure 1. Immunohistochemical, real-time PCR, and western blot analysis of the PP2A scaffold subunit (PP2A-A $\alpha / \beta)$ in prostate tissues and cancer cells. (A) The mean composite score is plotted and a significant $(P<0.001)$ downregulation of the scaffold subunit (PP2A-A $\alpha / \beta)$ was observed in the prostate cancer tissues compared with benign prostatic tissue. The representative figure shows immunoreactivity of PP2A-A $\alpha / \beta$ in benign prostate and prostate cancer tissues. A distinct nuclear to diffused cytoplasmic staining was observed in benign tissue, whereas almost no staining was observed in the cancerous prostate tissues (black arrows). (B) Real-time PCR analysis using primers specific for PP2A-A $\alpha / \beta$ in LNCaP C-33, C-81, PC-3, and PC-3M shows downregulation of PP2A-A $\alpha / \beta$ in Al-LNCaP C-81 compared with AD-C-33 cells. Similarly, the $\mathrm{PC}-3$ cells show a higher expression of PP2A-A $\alpha / \beta$ than in PC-3M. $\beta$-Actin was used as an internal control. (C) Western blot analysis shows a decreased expression of PP2A-A $\alpha / \beta$ in high metastatic cells (PC-3M, C-81) compared with low metastatic cells (PC-3, C-33). 


\begin{tabular}{|c|c|c|c|c|c|c|c|c|c|c|c|c|}
\hline & \multicolumn{4}{|c|}{ PP2A-C } & \multicolumn{4}{|c|}{ PP2A-B' $\gamma$} & \multicolumn{4}{|c|}{ PP2A-A $\alpha / \beta$} \\
\hline $\begin{array}{l}\text { Tissue } \\
\text { type }\end{array}$ & Pos. & Neg. & Total & $\begin{array}{c}P \text {-value } \\
\left.\text { ( } \chi^{2} \text { test }\right)\end{array}$ & Pos. & Neg. & Total & $\begin{array}{c}P \text {-value } \\
\left(\chi^{2} \text { test }\right)\end{array}$ & Pos. & Neg. & Total & $\begin{array}{c}P \text {-value } \\
\left.\text { ( } \chi^{2} \text { test }\right)\end{array}$ \\
\hline Benign & $28(90.3 \%)$ & $3(9.7 \%)$ & 31 & 0.6 & $10(52.6 \%)$ & 9 (47.4\%) & 19 & 0.0002 & $14(48.2 \%)$ & 15 (51.8\%) & 29 & $<0.001$ \\
\hline \multirow[t]{2}{*}{ Cancer } & 58 (90.6\%) & 6 (9.4\%) & 64 & & 22 (13.4\%) & $141(86.6 \%)$ & 163 & & 18 (12.3\%) & 128 (87.7\%) & 146 & \\
\hline & 86 & 9 & 95 & & 32 & 150 & 182 & & 32 & 143 & 175 & \\
\hline
\end{tabular}

statistically significant $(P$-value $<0.001)$ between benign and malignant prostate tissue (Figure 1A and Table 2). On the basis of the staining analysis, we observed that there is a gradual loss of $\mathrm{PP} 2 \mathrm{~A}-\mathrm{A} \alpha / \beta$ expression during $\mathrm{PCa}$ pathogenesis, strongest being in normal and benign and very weak expression in the cancer tissue sections.

Expression of the PP2A-A $\alpha / \beta$ scaffold subunit in low and high metastatic PCa cells. Upon performing quantitative real-time $\mathrm{PCR}$, we observed that the expression of $\mathrm{PP} 2 \mathrm{~A}-\mathrm{A} \alpha / \beta$ was downregulated at the mRNA level (2.1-fold less) in the highly metastatic PC-3M cells when compared with the low metastatic PC-3 cells $(P<0.01)$ (Figure $1 B)$. Similar results were observed in high metastatic LNCaP (C-81) cells as compared with low metastatic LNCaP $(\mathrm{C}-33)$ cells $(P<0.001)$. In the LNCaP $(\mathrm{C}-81)$ cells, the PP2A-A $\alpha / \beta$ was 2.8 -fold less than the $\mathrm{LNCaP}(\mathrm{C}-33)$ cells (Figure $1 \mathrm{~B}$ ). At the protein level, both in the PC-3M and LNCaP (C-81) cells, a significantly low expression of $\mathrm{PP} 2 \mathrm{~A}-\mathrm{A} \alpha / \beta$ was observed compared with PC-3 and LNCaP (C-33) cells, which implies a downregulation of $\mathrm{PP} 2 \mathrm{~A}-\mathrm{A} \alpha / \beta$ in androgen-insensitive and highly metastatic PCa cells (Figure 1C).

Downregulation of PP2A-A $\alpha / \beta$ scaffold subunit leads to increase of phosphorylated Akt in PCa cells. On the basis of the fact that AKT is one of the major substrate of PP2A and AKT activation is dependent on the phosphorylation at serine residue 473. We further assessed AKT phosphorylation in the low metastatic PC-3 and high metastatic PC-3M cells, as well as in AD LNCaP (C-33) and AI LNCaP (C-81) cells by western blotting. Here, we compared the endogenous levels of phosphorylation on serine 473 of AKT in relation to that of $\mathrm{PP} 2 \mathrm{~A}-\mathrm{A} \alpha / \beta$ downregulation in PCa cells. Phosphorylation of AKT-Ser473 increases in PC-3M and LNCaP (C-81) cells as compared with PC-3 and LNCaP (C-33) cells (Supplementary Figure 1).

Immunohistochemistry of the regulatory subunit $\mathbf{P P}^{2 A-B^{\prime}} \gamma$ in benign and PCa tissues. In this analysis, 182 prostate tissue spots were stained. Out of 163 cancer tissue spots, 13.4\% (22 out of 163) were positive for $\mathrm{PP} 2 \mathrm{~A}-\mathrm{B}^{\prime} \gamma$, whereas $52.6 \%$ (10 out of 19) benign tissue were positive (Figure $2 \mathrm{~A}$ and Table 2). Localisation of PP2A$\mathrm{B}^{\prime} \gamma$ was mostly in the nucleus and was also present in the cytoplasm of epithelial cells. No expression of $\mathrm{PP}^{2 \mathrm{~A}-\mathrm{B}^{\prime} \gamma \text { was }}$ observed in the surrounding stroma. Upon comparing prostatic adenocarcinoma and benign prostatic tissue, the expression of $\mathrm{PP} 2 \mathrm{~A}-\mathrm{B}^{\prime} \gamma$ was observed to be significantly decreased in the adenocarcinoma tissues $(P$-value $=0.0002)$, while it was uniformly lost in the highly metastatic cancer cells (Figure 2A and Table 2).

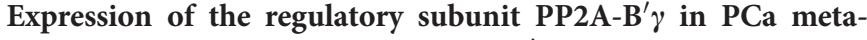
static cells. Regulatory subunit $\mathrm{PP} 2 \mathrm{~A}-\mathrm{B}^{\prime} \gamma$ was significantly downregulated at both the transcript and protein levels in highly metastatic PCa cells vs low metastatic PCa cells. The expression of $\mathrm{PP} 2 \mathrm{~A}-\mathrm{B}^{\prime} \gamma$ mRNA was significantly low in LNCaP (C-81) cells (3.33-fold less) when compared with LNCaP (C-33) cells
$(P<0.05)$. In the PC-3 model, PC-3M cells (highly metastatic) had 1.5-fold less expression of PP2A- $\mathrm{B}^{\prime} \gamma$ mRNA than in PC-3 cells (low metastatic) (Figure 2B) $(P=0.6)$. At the protein level, the expression of PP2A- $\mathrm{B}^{\prime} \gamma$ was low in the highly metastatic PC-3M and LNCaP (C-81) cells when compared with low metastatic PC-3 and $\mathrm{LNCaP}(\mathrm{C}-33)$ cells (Figure $2 \mathrm{C}$ ), indicating a gradual loss of $\mathrm{PP} 2 \mathrm{~A}-\mathrm{B}^{\prime} \gamma$ expression with the progression of PCa.

Immunoreactivity of PP2A-C catalytic subunit in benign and malignant PCa tissue sample. We demonstrated PP2A-C expression pattern in benign prostatic hyperplasia $(\mathrm{BPH})$ and $\mathrm{PCa}$ tissue sample by performing IHC on commercially available PCa tissue microarrays. We screened a total of 95 tissue spots where 64 spots were malignant and 31 were benign $(\mathrm{BPH})$ spots. Protein phosphatase type $2 \mathrm{~A}-\mathrm{C}$ was equally expressed in both $\mathrm{BPH}$ and cancer (Figure $3 \mathrm{~A}$ and Table 2). With respect to localisation, $\mathrm{PP} 2 \mathrm{~A}-\mathrm{C}$ was primarily expressed in the cytoplasm and the nucleus (Figure $3 \mathrm{~A})$. The positivity of PP2A-C expression in $\mathrm{BPH} /$ benign and malignant tissues were $90.3 \%$ (28 out of 31 ) and $90.6 \%$ (58 out of 64), respectively, and the difference was not statistically significant $(P$-value $=0.6)($ Figure $3 \mathrm{~A}$ and Table 2$)$.

Expression of PP2A-C at mRNA and protein levels. In addition to performing immunohistochemical analysis in various premalignant and malignant $\mathrm{PCa}$ tissues, the expression pattern of PP2A-C was analysed at the mRNA and protein levels in PC-3 (low and high metastatic cell lines) and LNCaP (C-33 and C-81) PCa cell line models. For quantitative analysis, PP2A-C expression at the mRNA level was assessed by real-time PCR, where both PC-3 and PC-3M cells had comparable expression $(P=0.3)$ with nonsignificant $P$-value and a similar expression pattern was obtained in LNCaP C-33 (AD) and LNCaP C-81 (AI) cell lines (Figure $3 \mathrm{~B})(P=0.9)$. Western blot studies further confirmed the mRNA expression pattern, as there was no difference in the level of PP2A-C protein between LNCaP (C-33) and LNCaP (C-81) cells, as well as between PC-3 and PC-3M cells (Figure $3 \mathrm{C}$ ). Thus, the expression of $\mathrm{PP} 2 \mathrm{~A}-\mathrm{C}$ is constant at both the mRNA and protein levels in those paired cell lines.

Effects of transient knockdown of PP2A-A $\alpha$ on Akt signalling and invasive potential of PCa cells. By extending our previous observation on the scaffold subunit, two siRNA oligos against the PP2A-A $\alpha$ were used for transient knockdown of PP2A-A $\alpha$ in PC-3 and LNCaP cells. Scramble oligo-transfected cells were used as a control. Lysates were collected and probed with the respective antibodies. We looked at the impact of PP2A-A $\alpha$ knockdown on the activity and protein levels of Akt, $\beta$-catenin, and FAK protein levels in PC-3 cells. As a result, the transient knockdown of PP2A$\mathrm{A} \alpha$ in $\mathrm{PCa}$ cells led to a remarkable increase in the level of phospho-Akt, active $\beta$-catenin, and phospho-FAK compared with the SCR siRNA-transfected control (Figure 4A). Similar results were also demonstrated in $\mathrm{LNCaP}$ (C-33 and C-81) cell line model system, which showed that transient knockdown of PP2A-A $\alpha$ 
A
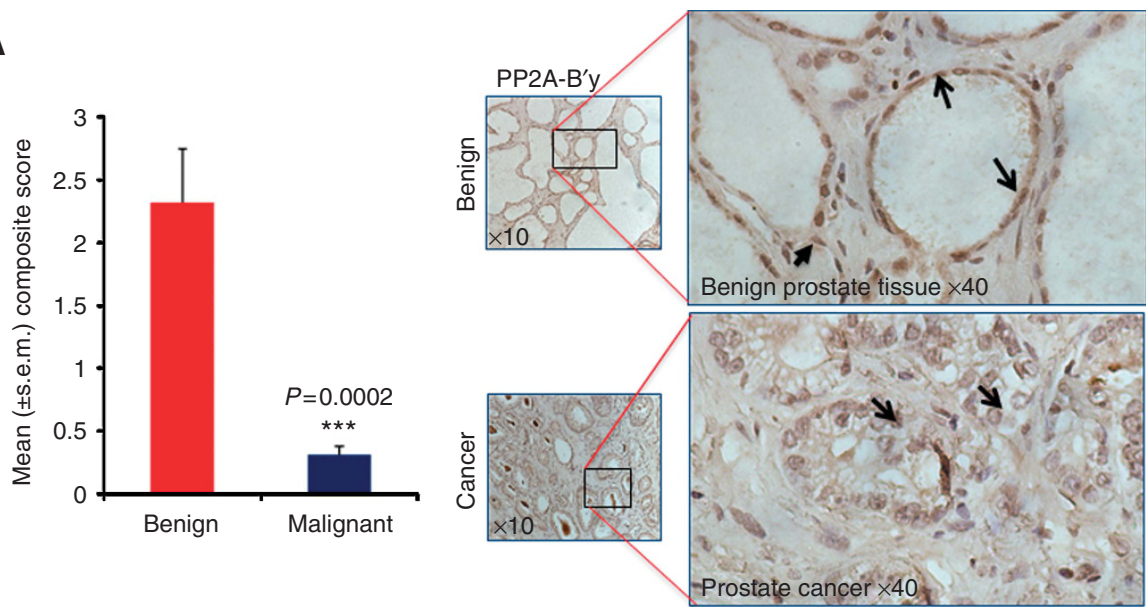

B
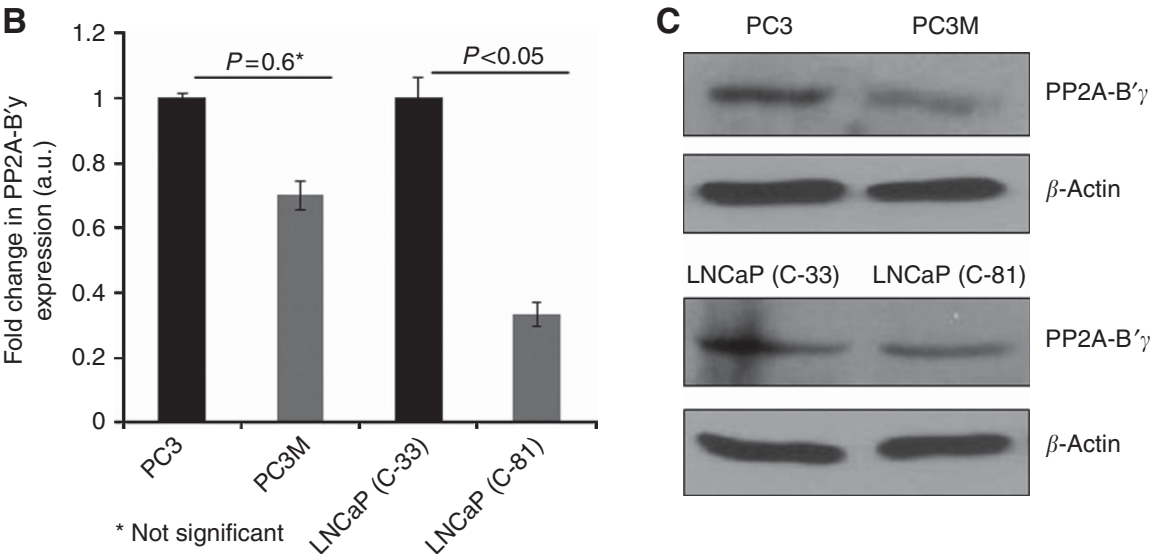

Figure 2. Protein phosphatase $2 A$ regulatory subunit (PP2A- $\left.B^{\prime} \gamma\right)$ expression pattern in benign and prostate cancer tissues and cell lines.

(A) Immunohistochemical analysis of PP2A regulatory subunit (PP2A-B' $\gamma$ ) in benign and prostate cancer tissues. The mean composite score shows statistically significant $(P<0.001)$ downregulation of the regulatory subunit (PP2A-B' $\gamma)$ in prostate cancer tissues compared with benign prostatic tissue. Representative tissue spots show prominent nuclear and cytoplasmic staining in benign tissue, whereas almost no staining was observed in the cancerous tissue (black arrows). (B) Quantitative real-time RT-PCR shows that regulatory (PP2A-B' $\gamma$ ) subunit mRNA was significantly downregulated in Al LNCaP (C-81) PCa cells compared with AD LNCaP (C-33) PCa cells in the LNCaP model. No significant downregulation of PP2A-B' $\gamma$ mRNA was observed between PC-3 and its metastatic variant PC-3M cells. $\beta$-Actin was used as an internal control. (C) Immunoblotting analysis shows a significant decrease of PP2A-B' $\gamma$ protein in LNCaP (C-81) and PC-3M cells compared with LNCaP (C-33) and PC-3 cells, respectively. $\beta$-Actin was used as loading control.

resulted in enhanced AKT-Ser473 phosphorylation with no change in the total AKT levels (Supplementary Figures 2 and 3).

To investigate the effect of $\mathrm{PP} 2 \mathrm{~A}-\mathrm{A} \alpha$ on cell motility, migration and wound healing assays were performed in PC-3 cells in which $\mathrm{PP} 2 \mathrm{~A}-\mathrm{A} \alpha$ was transiently knocked down for $48 \mathrm{~h}$. As shown in Figure $4 \mathrm{~B}$, the migration potential of PP2A-A $\alpha$ knockdown cells significantly increased at $24 \mathrm{~h}$ in transwell migration assay. Similarly, quantification of the migration distance from wound healing assays showed that wound closure in PP2A-A $\alpha$ knockdown cells was significantly higher than the control cells transfected with SCR siRNA (Figure 4C). These results indicate that specific knockdown of $\mathrm{PP} 2 \mathrm{~A}-\mathrm{A} \alpha$ results in increased migration and motility property of PCa cells.

\section{DISCUSSION}

It has been postulated that phosphorylation and dephosphorylation are coordinated events that are governed and balanced by the activity of kinases and phosphatases (Bononi et al, 2011). Protein phosphatase type $2 \mathrm{~A}$ is a ubiquitously expressed serine/threonine phosphatase, which acts as key dephosphorylating enzyme for various signal-transduction pathways in eukaryotic cells (Millward et al, 1999). Although numerous studies have shown the role of PP2A as a tumour suppressor, the regulatory role of individual subunits, which is deregulated in cancer, remains to be defined. Recent evidence from the genomic and proteomic data clearly defines the critical role of PP2A subunits under both normal physiological and oncogenic conditions by regulating particular substrates (Muneer et al, 2002; Sablina et al, 2007). Further, because of the existence of several isoforms for each subunit, their ability to form a variety of heterotrimers (70 different forms) could explain the diversity of the PP2A holoenzyme complex and its functional distinction (Janssens and Goris, 2001; Mumby, 2007; Janssens et al, 2008). Thus, decreased activity of any of these subunits might contribute to the proliferation of cancer cells. This study focuses on the differential expression of various PP2A subunits in benign and malignant prostatic tissues as well as how this differential expression favours proliferation in the PCa cell model system. To study the specific role of various subunits of PP2A, we have compared the differential expression pattern of $\mathrm{PP} 2 \mathrm{~A}-\mathrm{A} \alpha / \beta,-\mathrm{B}^{\prime} \gamma$, and $-\mathrm{C}$ in benign prostatic tissue and malignant PCa tissue spots on a prostate TMA and in the clinically relevant 
A

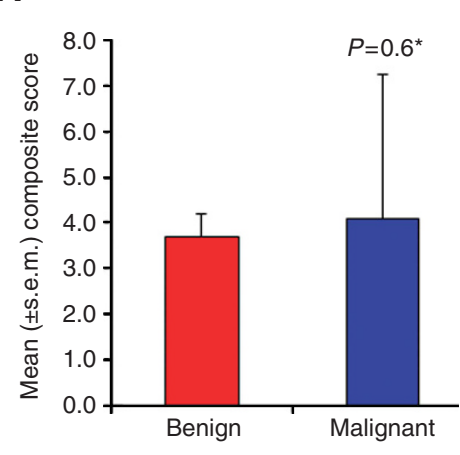

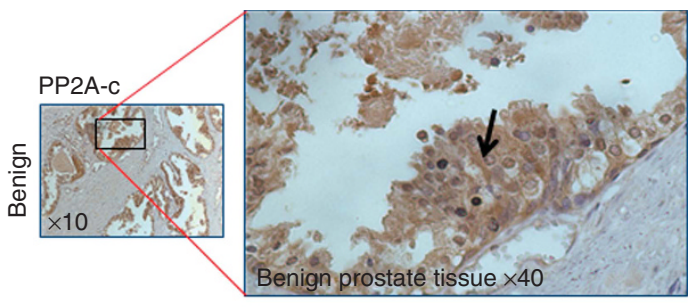

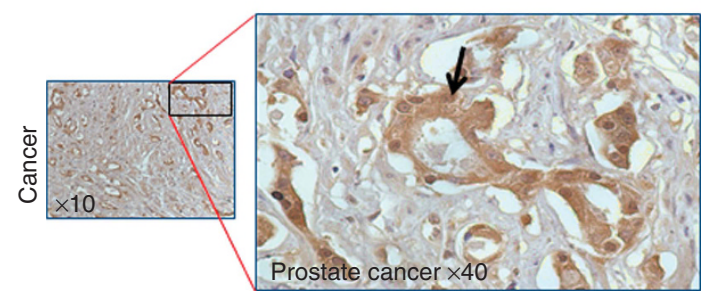

B

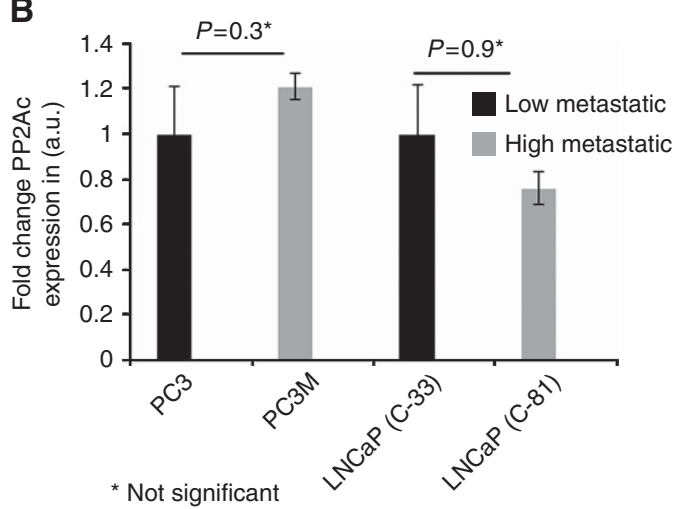

C

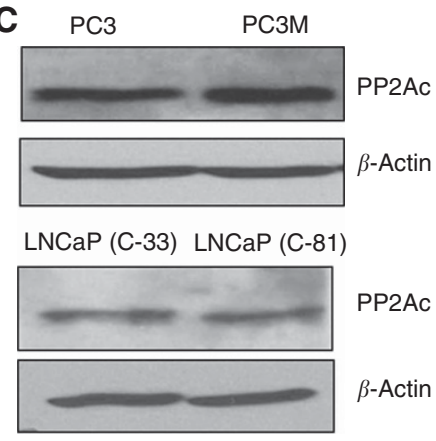

Figure 3. Expression of PP2A catalytic subunit (PP2AC) in benign and prostate cancer tissues and cell lines. (A) Immunohistochemical analysis of PP2AC staining between benign and prostate cancer did not show any significant difference using a composite score method. Representative images of prostate tissues stained for PP2AC show cytoplasmic and nuclear staining (black arrows) in both BPH and prostate tumour. (B) Real-time PCR-based measurement of PP2A catalytic (PP2AC) subunit in prostate cancer cells. Expression of PP2AC at the transcript level is similar in both the prostate cancer cell models (PC-3 and LNCaP). (C) Western blot analysis showing an equal expression of PP2AC in both the prostate cancer cell model systems (PC-3 and LNCaP cells) and $\beta$-actin was used as loading control.

PCa cell model system PC-3 and LNCaP cells, to explore the mechanism in both the AD and the AI status of PCa.

Previous work in various cancers such as breast, lung, and colon have shown that the cancer-derived mutant form PPP2R1B (PP2A structural subunit) may have an impaired function because of its inability to form a complex with the catalytic and regulatory subunits (Calin et al, 2000; Ruediger et al, 2001; Tamaki et al, 2004). Furthermore, Sablina et al (2007) have reported that the loss of the PP2A-A (scaffold) subunit can induce oncogenic transformation through activation of small GTPase RalA (Sablina et al, 2007). In our study, we observed a statistically significant reduction of the PP2A-A $\alpha / \beta$ scaffold subunit in cancer specimens when compared with benign tissues. Similarly, the endogenous level of PP2A-A $\alpha$ at both the protein and mRNA levels were significantly downregulated in C-33 and PC-3 cells as compared with C-81 and PC-3M high metastatic cell lines. Therefore, our study is in support of the somatic mutations of the PP2A-A $\alpha$ and $-\beta$ subunits observed in colon, breast, and lung cancers, stating that alterations or loss of any of PP2A-A $\alpha$ and $-\beta$ subunits can lead to an inhibitory effect by interfering with the interaction of the PP2A scaffold subunit and the PP2A catalytic subunit or regulatory subunit (Calin et al, 2000; Takagi et al, 2000; Tamaki et al, 2004). Also, earlier reports indicate that the loss of expression of the PP2A structural subunit may be an important factor for the failure of integrin dephosphorylation in breast cancer cells (Suzuki and Takahashi, 2003).

Second, we looked at the possible involvement of the regulatory (B) subunit in both tissues as well as in the cell line model systems.
Previous reports from many researchers have provided their ideology of PP2A interacting with small $t$ (SV40 small t-antigen) protein, implying that small $t$ might be directly interacting with the dimer or it displaces the third regulatory subunit from the holoenzyme complex. Among the PP2A-B family members, B56 or $\mathrm{B}^{\prime}$ will participate in several regulating mechanisms, such as signalling, cell cycle check point, development, and apoptosis (Seeling et al, 1999; Li et al, 2002; Yang et al, 2003; Chen et al, 2004; Van Kanegan et al, 2005; Margolis et al, 2006). Studies from Chen et al (2004) have provided evidence that suppressing B56 $\gamma$ seemed to mimic the ST-induced cell transformation, rather than the B55 regulatory subunit, thus inhibiting the PP2A-specific phosphatase activity (Chen et al, 2004). Our results show that immunohistochemical expression for the $\mathrm{PP}^{2} \mathrm{~A}-\mathrm{B}^{\prime} \gamma$ subunit displayed a higher expression in benign tissues as compared with the malignant prostate tissue. Similarly, the mRNA and the endogenous level of the PP2A-B ${ }^{\prime} \gamma$ subunit was strongly expressed in both AD C-33 and PC-3 (AI) cells when compared with AI C-81 and high metastatic PC-3M cells. This finding is consistent with the observation of Sablina et al (2010), who demonstrated that the suppression of specific regulatory subunits B56 $\alpha$, B56 $\gamma$, and PR72/ 130, as well as PTPA, induced a transformed phenotype, implicating their role in cell transformation. Also, it is suggested that $\mathrm{PP} 2 \mathrm{~A}-\mathrm{B}^{\prime} \gamma$ was involved in the regulation of WNT signalling by interacting with APC tumour suppressor protein, thereby interfering with the APC-Axin complex formation, which may have a destabilising effect on $\beta$-catenin, and thus indirectly prevent 
A
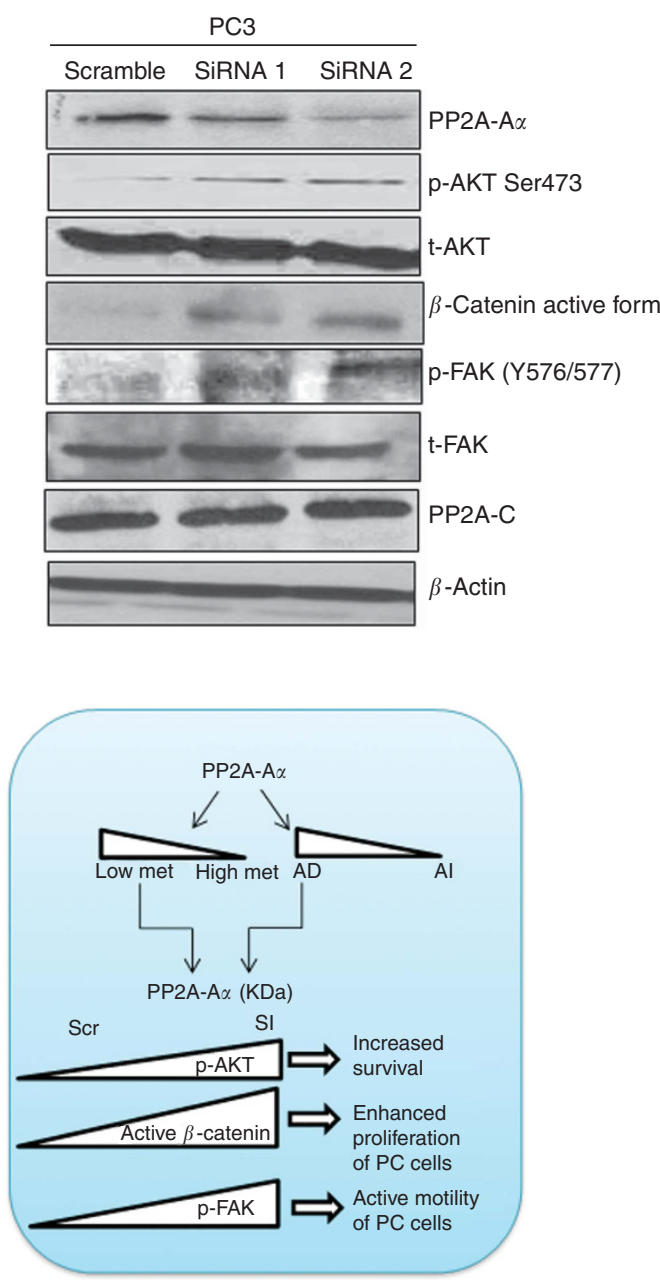

B

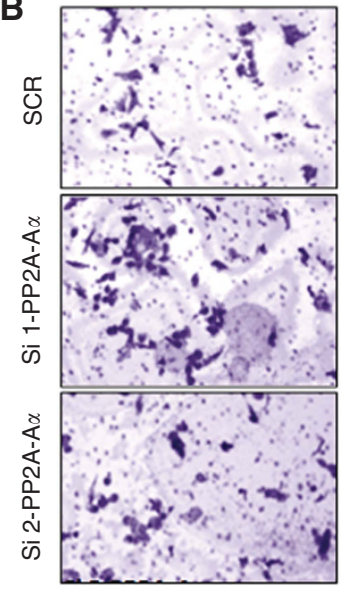

C
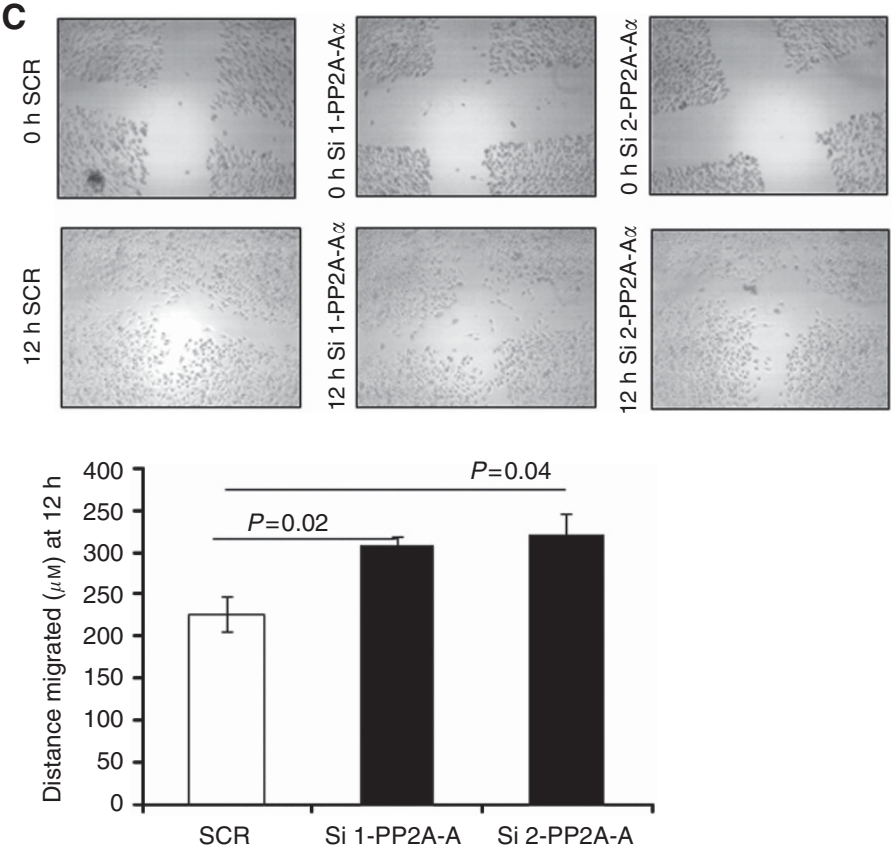

Figure 4. Effect of transient knockdown of PP2A-A $\alpha$ on Akt, $\beta$-catenin, and FAK signalling and cell motility assays in prostate cancer (PC) cells. (A) Upon knockdown of PP2A-A $\alpha$, phosphorylation of AKT-Ser473 in PC-3 cells was increased. In addition, immunoblot analysis of PC-3 cells demonstrates increased phosphorylation of FAK-Tyr576/577 along with $\beta$-catenin activation after transient knockdown of PP2A-A $\alpha$. (B) Also, the migration potential of PC cells was increased after transient knockdown of PP2A-A $\alpha$ at $48 \mathrm{~h}$. Cells that are migrated through the 8- $\mu \mathrm{m}$ pores of a polyethylene terephthalate (PET) membrane were quantified in 10 random fields and plotted. (C) Protein phosphatase type $2 \mathrm{~A}-\mathrm{A} \alpha$ was transiently knocked down in PC-3 PC cells and grown for $48 \mathrm{~h}$. Cells were then trypsinised and reseeded at the cell density of $1 \times 10^{5}$ per plate. PC-3 PC cells were grown until they achieved a confluent monolayer and a scratch was made using a sterile pipette tip. Introduced wounds were photographed at 0 and $12 \mathrm{~h}$. The distance migrated by the PC-3 cells were quantified by measuring the distance migrated from the 0 to $12 \mathrm{~h}$. Thus, the knock down of the scaffold subunit (PP2A-A $\alpha$ ) demonstrated the increasing metastatic potential as a consequence of reduced levels. Thus, western blot analysis showing that phospho (p)-Akt, active $\beta$-catenin, and phospho-FAK protein levels directly correlates with cell survival, proliferative capacity, and invasive potential of PC cells but no change in the respective total proteins. Furthermore, the cell motility analysis through transwell migration and wound closure analysis on PC-3 cells after transient knockdown of PP2A-A $\alpha$ at $48 \mathrm{~h}$ suggests that the knockdown of PP2A-A $\alpha$ may have a role in increased migration capacity of PC cells.

transcriptional activation of $\beta$-catenin target genes such as MYC (c-myc) and CCND1 (Cyclin D1) (Seeling et al, 1999). The alteration/loss of expression of $\mathrm{PP} 2 \mathrm{~A}-\mathrm{B}^{\prime} \gamma$ observed in our study may contribute to enhanced $\beta$-catenin activation, leading to the transcription of $\beta$-catenin into the nucleus and resulting in malignant transformation. Further, $\mathrm{Li}$ et al (2007) was the first to report that specific regulatory subunit B56 $\gamma$-containing complexes of PP2A function as tumour suppressors by dephosphorylating p53 at Thr55, which further leads to p53 degradation. Specifically, these reports suggest that the loss of B56 $\gamma$ subunit expression would result in a loss of PP2A phosphatase activity and thereby induce cellular transformation (Li et al, 2007).

In our earlier study, we have demonstrated that $P P P 2 C A$, which encodes for the catalytic subunit ( $\alpha$-isoform) of the PP2A-C, was found to be downregulated in AI PCa cell line as compared with $\mathrm{AD}$ (Singh et al, 2008). In addition, Prowatke et al (2007) also showed the downregulation of the $\beta$-isoform of the PP2A catalytic subunit in prostate carcinoma using TMA (Prowatke et al, 2007). In the present communication, we have demonstrated that there was no significant difference in the expression of PP2A-C between 
benign and $\mathrm{PCa}$ tissue spots, with regard to $\mathrm{AD}$ and $\mathrm{AI}$ cells (LNCaP) and between low metastatic and high metastatic (PC-3 and PC-3M) cells both at the protein and mRNA levels. The available oncomine data in gastric cancer also supports that the equal existence of catalytic subunit (remained unchanged) in both normal and cancerous tissues. Although there was a slight difference in the PP2A-C expression pattern between benign and malignant prostate tissues, the difference was statistically insignificant. The results in this study support the notion that the synergistic involvement of the catalytic, regulatory, and scaffold subunits are required for the entire phosphatase activity of PP2A. This study supports the mechanism of autoregulation of PP2A (Baharians and Schonthal, 1998), which exerts a constant level of PP2A-C nonspecific expression in tissues that are independent of hormone status. Early investigations demonstrated that post-translational modification of PP2A catalytic subunit modified by methylation or phosphorylation (at tyrosine and threonine residues) is a crucial determinant for $\mathrm{PP} 2 \mathrm{~A}$ regulation and holoenzyme complex formation. These modification are governed by leucine carboxyl methyltransferase 1 and phosphatase methyl esterase. Like the catalytic subunit, the regulatory subunit of $\mathrm{PP} 2 \mathrm{~A}$ PR61/B' is also subjected to post-translational modification (phosphorylation) (Longin et al, 2008). However, this modification is a context-dependent process. Serine or proline phosphorylation of PR61/B' subunit by ERK would lead to its dissociation from the catalytic or holoenzyme complex (Letourneux et al, 2006; Cho and $\mathrm{Xu}, 2007)$. In contrast, phosphorylation of $\mathrm{PR} 61 / \mathrm{B}^{\prime}$ subunit at serine 37 by Chk1 would specifically favour formation of holoenzyme complex assembly (Margolis et al, 2006). Thus, in the holoenzyme regulation apart from the catalytic subunit posttranslational modifications of the other regulatory and scaffold subunits are equally important.

Finally, it is now well established that deregulation of PP2A signalling is considered to be a prerequisite for the development of malignant cells. More recently, it has been demonstrated that inhibition of PP2A activity leads to proliferation and survival of AI PCa cells through activation of AKT and ERK signalling (Bhardwaj et al, 2011). In addition, the direct evidence of PP2A as a tumour suppressor has been shown in a knock-in and knockout mouse model expressing E64D and E64G mutations (Ruediger et al, 2011). However, little is known about the nature of phosphosignalling networks associated with this malignant transformation of prostate (Westermarck and Hahn, 2008). Moreover, the enzymatic activity of a protein can be altered by reversible phosphorylation (Nolan et al, 1964). Considering the distinct role of $\mathrm{PP} 2 \mathrm{~A}$, which can regulate the phosphorylation of particular substrates involved in neoplastic transformation, further work was extended in the expressional analysis of the phosphorylation status of one of the PP2A substrate AKTs. The role of PP2A as a major negative regulator of the AKT pathway is well established in $\mathrm{PCa}$ (Li et al, 2005). Previous work has shown that the partial suppression of the endogenous $\mathrm{A} \alpha$ subunit leads to the activation of the AKT kinase (Chen et al, 2005). Furthermore, hyperactivation of AKT signalling has been shown in prostate cells as well as in advanced PCa tissues (Kreisberg et al, 2004). To determine whether the AKT pathway was altered in $\mathrm{PCa}$ (in vitro), we transiently knocked down PP2A-A $\alpha$ in PC-3 and C-33 cells for $48 \mathrm{~h}$. We found that transient knockdown of PP2A-A $\alpha$ in PC-3 and C-33 cells produced a more significant increase in the phosphorylated AKT level at the serine 473 residue as compared with the SCR-transfected control cells. In addition, through functional analysis, we observed a knock down of the scaffold subunit using PP2A-A $\alpha$ siRNA or antisense oligodeoxynucleotides, which significantly enhanced cell migration and invasion in PC-3 cell line. Our results imply the direct involvement of PP2A subunits in regulating growth and proliferation of AI PCa cells. Moreover, we observed that there is a perfect correlation between the level of AKT phosphorylation and the loss of expression of endogenous levels of the PP2A-A $\alpha$ subunit. This implies that the loss of expression or suppression of the PP2A scaffold subunit may contribute to the activation of the PI-3 kinase/AKT pathway and thus initiate oncogenesis and transformation of benign cells into PCa cells. We believe that alterations in the level of PP2A catalytic or the regulatory subunit in PCa cells may be critical in regulating the downstream targets (Seeling et al, 1999; Suzuki and Takahashi, 2003; Margolis et al, 2006; Li et al, 2007; Bhardwaj et al, 2011). The influence of PP2A on cellular dynamics such as cell adhesion, migration, and cytoskeleton dynamics were poorly understood. A series of events such as lamellipodium formation, actin-rich extension (filopodia), and focal adhesion formation are indicative of cellular migration (Ross et al, 2012). Protein phosphatase 2A has been shown to colocalise with $\beta 1$-integrin, which is required for FAK regulation (Young et al, 2002, 2003). Our studies corroborate earlier findings, which have demonstrated that PP2A inhibition resulted in enhanced hyperphosphorylation of FAK leading to cellular migration, enhanced motility, and cellular spreading activity (Slack et al, 2001; Young et al, 2002). These observations were substantially demonstrated in BL6 mouse melanoma cells, head and neck cancer, lung cancer, and other malignancies (Jackson et al, 1997; Meisinger et al, 1997; Ito et al, 2000). The data obtained in our study demonstrate that downregulation of PP2A scaffold subunit in PCa cells leads to enhanced cell spreading, migration, survival signaling, and increased viability. Furthermore, the FAK activation in the phospho-form of Y576/577 will define the crucial role of PP2A in adhesion and migration. In addition, the role of PP2A scaffold subunit in cellular communication can be evidenced by active $\beta$-catenin expression. Taken together, the results revealed the mechanistic insight into the functional role of PP2A subunit, specifically the scaffold subunit in promoting progression to androgen independence. Thus, PP2A is likely to

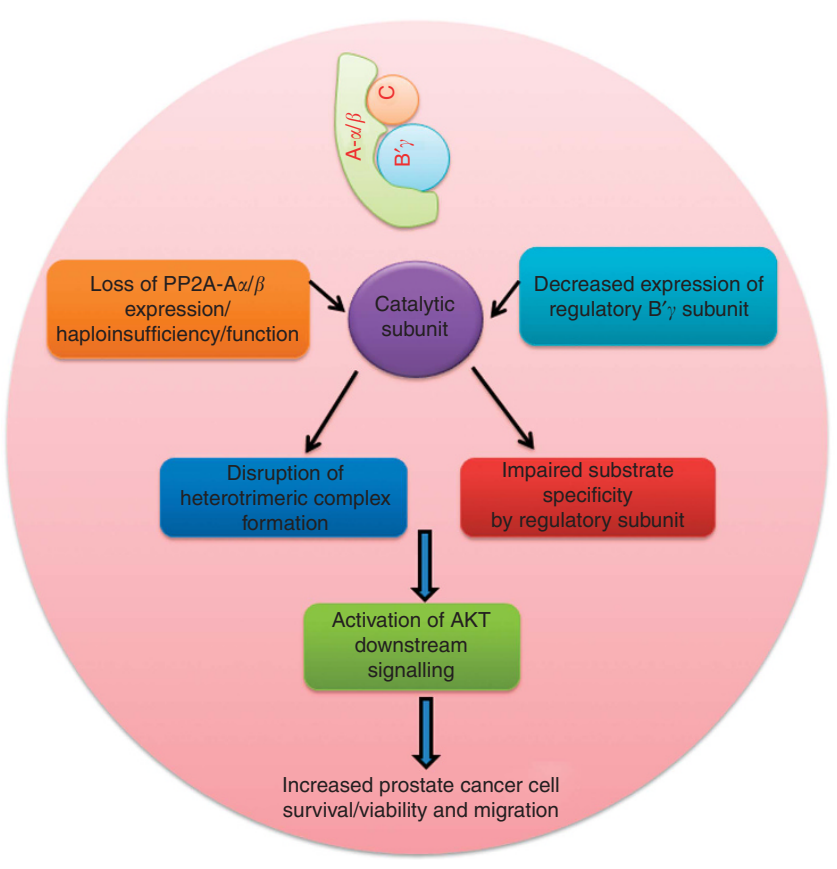

Figure 5. Diagrammatic representation of the loss of PP2A subunits in prostate cancer pathogenesis. Schematic representation of loss/ reduced expression levels of the scaffold subunit (PP2A-A $\alpha / \beta)$ and the regulatory subunit $\left(\mathrm{PP} 2 \mathrm{~A}-\mathrm{B}^{\prime} \gamma\right)$, thereby leading to the disruption of heterotrimeric complex formation and impaired substrate specificity. Thus, the regulatory and scaffold subunit of PP2A may have a role in prostate cancer progression. Mechanistically, transient knockdown of PP2A-A $\alpha$ leads to increased phospho-AKT level in prostate cancer cells. 
play an integral role in tumour suppressor network, which is partially regulated by $\mathrm{AKT} / \mathrm{FAK} / \beta$-catenin in promoting $\mathrm{AI}$ growth of $\mathrm{PCa}$.

In conclusion, based on our studies we report that the expression of the PP2A was downregulated during PCa progression primarily due to the downregulation of the regulatory and scaffold subunits and not the catalytic subunit. The downregulation of the scaffold subunit further emphasises the fact that it was unable to organise both the regulatory and catalytic subunit together for its functional role of cellular transformation (Figure 5). Further, based on this study, it is very clear that even if there is no change in the constitutive expressional level of the $\mathrm{C}$ subunit, a differential expression or loss of expression on A and B subunits may have an influential role in PCa progression. Thus, this study on the downregulation of the PP2A subunits has a critical role in $\mathrm{PCa}$ pathogenesis and progression.

\section{ACKNOWLEDGEMENTS}

This work was supported, in part, by grants from the Department of Defense (PC074289) and the National Institutes of Health (R01 CA138791). The funders had no role in study design, data collection and analysis, decision to publish, or preparation of the manuscript.

\section{AUTHOR CONTRIBUTIONS}

SKB, PP and PS: conceived and designed the experiments;PP, PS, SD and SR: performed experiments; SKB, PP, PS PPM, KD, ML and YY: analysed the data;SKB: contributed reagents/materials/ analysis tools; and SLJ: served as the certified pathologist for scoring of haematoylin and eosin, as well as scoring of IHC slides. PS and PP wrote the paper. All authors read and approved the final manuscript.

\section{CONFLICT OF INTEREST}

The authors declare no conflict of interest.

\section{REFERENCES}

Baharians Z, Schonthal AH (1998) Autoregulation of protein phosphatase type 2A expression. J Biol Chem 273(30): 19019-19024.

Bhardwaj A, Singh S, Srivastava SK, Honkanen RE, Reed E, Singh AP (2011) Modulation of protein phosphatase $2 \mathrm{~A}$ activity alters androgenindependent growth of prostate cancer cells: therapeutic implications. Mol Cancer Ther 10(5): 720-731.

Bononi A, Agnoletto C, De ME, Marchi S, Patergnani S, Bonora M, Giorgi C, Missiroli S, Poletti F, Rimessi A, Pinton P (2011) Protein kinases and phosphatases in the control of cell fate. Enzyme Res 2011: 329098.

Brinkmann AO (2001) Lessons to be learned from the androgen receptor. Eur J Dermatol 11(4): 301-303.

Calin GA, di Iasio MG, Caprini E, Vorechovsky I, Natali PG, Sozzi G, Croce CM, Barbanti-Brodano G, Russo G, Negrini M (2000) Low frequency of alterations of the alpha (PPP2R1A) and beta (PPP2R1B) isoforms of the subunit A of the serine-threonine phosphatase $2 \mathrm{~A}$ in human neoplasms. Oncogene 19(9): 1191-1195.

Chen W, Arroyo JD, Timmons JC, Possemato R, Hahn WC (2005) Cancer-associated PP2A Aalpha subunits induce functional haploinsufficiency and tumorigenicity. Cancer Res 65(18): 8183-8192.

Chen W, Possemato R, Campbell KT, Plattner CA, Pallas DC, Hahn WC (2004) Identification of specific PP2A complexes involved in human cell transformation. Cancer Cell 5(2): 127-136.
Cho US, Morrone S, Sablina AA, Arroyo JD, Hahn WC, Xu W (2007) Structural basis of PP2A inhibition by small $t$ antigen. PLoS Biol 5(8): e202.

Cho US, Xu W (2007) Crystal structure of a protein phosphatase 2A heterotrimeric holoenzyme. Nature 445(7123): 53-57.

Chuu CP, Kokontis JM, Hiipakka RA, Fukuchi J, Lin HP, Lin CY, Huo C, Su LC (2011) Androgens as therapy for androgen receptor-positive castration-resistant prostate cancer. J Biomed Sci 18: 63.

Cohen P (2001) The role of protein phosphorylation in human health and disease. The Sir Hans Krebs Medal Lecture. Eur J Biochem 268(19): 5001-5010.

Esplin ED, Ramos P, Martinez B, Tomlinson GE, Mumby MC, Evans GA (2006) The glycine 90 to aspartate alteration in the Abeta subunit of PP2A (PPP2R1B) associates with breast cancer and causes a deficit in protein function. Genes Chromosomes Cancer 45(2): 182-190.

Grochola LF, Vazquez A, Bond EE, Wurl P, Taubert H, Muller TH, Levine AJ, Bond GL (2009) Recent natural selection identifies a genetic variant in a regulatory subunit of protein phosphatase $2 \mathrm{~A}$ that associates with altered cancer risk and survival. Clin Cancer Res 15(19): 6301-6308.

Hankey BF, Feuer EJ, Clegg LX, Hayes RB, Legler JM, Prorok PC, Ries LA, Merrill RM, Kaplan RS (1999) Cancer surveillance series: interpreting trends in prostate cancer-part I: evidence of the effects of screening in recent prostate cancer incidence, mortality, and survival rates. J Natl Cancer Inst 91(12): 1017-1024.

Hoffman RM (2011) Clinical practice. Screening for prostate cancer. N Engl J Med 365(21): 2013-2019.

Igawa T, Lin FF, Lee MS, Karan D, Batra SK, Lin MF (2002) Establishment and characterization of androgen-independent human prostate cancer LNCaP cell model. Prostate 50(4): 222-235.

Inagaki N, Ito M, Nakano T, Inagaki M (1994) Spatiotemporal distribution of protein kinase and phosphatase activities. Trends Biochem Sci 19(11): $448-452$.

Ito A, Kataoka TR, Watanabe M, Nishiyama K, Mazaki Y, Sabe H, Kitamura Y, Nojima H (2000) A truncated isoform of the PP2A B56 subunit promotes cell motility through paxillin phosphorylation. EMBO J 19(4): $562-571$.

Jackson J, Meisinger J, Patel S, Lim ZC, Vellody K, Metz R, Young MR (1997) Protein phosphatase-2A associates with the cytoskeleton to maintain cell spreading and reduced motility of nonmetastatic Lewis lung carcinoma cells: the loss of this regulatory control in metastatic cells. Invas Metast 17(4): 199-209.

Janssens V, Goris J (2001) Protein phosphatase 2A: a highly regulated family of serine/threonine phosphatases implicated in cell growth and signalling. Biochem J 353: 417-439.

Janssens V, Longin S, Goris J (2008) PP2A holoenzyme assembly: in cauda venenum (the sting is in the tail). Trends Biochem Sci 33(3): $113-121$.

Kamibayashi C, Estes R, Lickteig RL, Yang SI, Craft C, Mumby MC (1994) Comparison of heterotrimeric protein phosphatase $2 \mathrm{~A}$ containing different B subunits. J Biol Chem 269(31): 20139-20148.

Kreisberg JI, Malik SN, Prihoda TJ, Bedolla RG, Troyer DA, Kreisberg S, Ghosh PM (2004) Phosphorylation of Akt (Ser473) is an excellent predictor of poor clinical outcome in prostate cancer. Cancer Res 64(15): 5232-5236.

Kremmer E, Ohst K, Kiefer J, Brewis N, Walter G (1997) Separation of PP2A core enzyme and holoenzyme with monoclonal antibodies against the regulatory A subunit: abundant expression of both forms in cells. Mol Cell Biol 17(3): 1692-1701.

Letourneux C, Rocher G, Porteu F (2006) B56-containing PP2A dephosphorylate ERK and their activity is controlled by the early gene IEX-1 and ERK. EMBO J 25(4): 727-738.

Li HH, Cai X, Shouse GP, Piluso LG, Liu X (2007) A specific PP2A regulatory subunit, B56gamma, mediates DNA damage-induced dephosphorylation of p53 at Thr55. EMBO J 26(2): 402-411.

Li L, Ittmann MM, Ayala G, Tsai MJ, Amato RJ, Wheeler TM, Miles BJ, Kadmon D, Thompson TC (2005) The emerging role of the PI3-K-Akt pathway in prostate cancer progression. Prostate Cancer Prostat Dis 8(2): $108-118$.

Li X, Scuderi A, Letsou A, Virshup DM (2002) B56-associated protein phosphatase $2 \mathrm{~A}$ is required for survival and protects from apoptosis in Drosophila melanogaster. Mol Cell Biol 22(11): 3674-3684. 
Longin S, Zwaenepoel K, Martens E, Louis JV, Rondelez E, Goris J, Janssens V (2008) Spatial control of protein phosphatase 2A (de)methylation. Exp Cell Res 314(1): 68-81.

Margolis SS, Perry JA, Forester CM, Nutt LK, Guo Y, Jardim MJ, Thomenius MJ, Freel CD, Darbandi R, Ahn JH, Arroyo JD, Wang XF, Shenolikar S, Nairn AC, Dunphy WG, Hahn WC, Virshup DM, Kornbluth S (2006) Role for the PP2A/B56delta phosphatase in regulating 14-3-3 release from Cdc25 to control mitosis. Cell 127(4): 759-773.

Meisinger J, Patel S, Vellody K, Bergstrom R, Benefield J, Lozano Y, Young MR (1997) Protein phosphatase-2A association with microtubules and its role in restricting the invasiveness of human head and neck squamous cell carcinoma cells. Cancer Lett 111(1-2): 87-95.

Millward TA, Zolnierowicz S, Hemmings BA (1999) Regulation of protein kinase cascades by protein phosphatase 2A. Trends Biochem Sci 24(5): 186-191.

Moniaux N, Chakraborty S, Yalniz M, Gonzalez J, Shostrom VK, Standop J, Lele SM, Ouellette M, Pour PM, Sasson AR, Brand RE, Hollingsworth MA Jain M, Batra SK (2008) Early diagnosis of pancreatic cancer: neutrophil gelatinase-associated lipocalin as a marker of pancreatic intraepithelial neoplasia. Br J Cancer 98(9): 1540-1547.

Mumby M (2007) PP2A: unveiling a reluctant tumor suppressor. Cell 130(1): 21-24.

Muneer S, Ramalingam V, Wyatt R, Schultz RA, Minna JD, Kamibayashi C (2002) Genomic organization and mapping of the gene encoding the PP2A B56gamma regulatory subunit. Genomics 79(3): 344-348.

Nolan C, Novoa WB, Krebs EG, Fischer EH (1964) Further studies on the site phosphorylated in the phosphorylase b to a reaction. Biochemistry 3: 542-551.

Perrotti D, Neviani P (2008) Protein phosphatase 2A (PP2A), a drugable tumor suppressor in Ph1 $(+)$ leukemias. Cancer Metast Rev 27(2): 159-168.

Prowatke I, Devens F, Benner A, Grone EF, Mertens D, Grone HJ, Lichter P, Joos S (2007) Expression analysis of imbalanced genes in prostate carcinoma using tissue microarrays. Br J Cancer 96(1): 82-88.

Rachagani S, Senapati S, Chakraborty S, Ponnusamy MP, Kumar S, Smith LM, Jain M, Batra SK (2011) Activated $\mathrm{Kras}^{12} \mathrm{D}$ is associated with invasion and metastasis of pancreatic cancer cells through inhibition of E-cadherin. Br J Cancer 104(6): 1038-1048.

Ross SH, Spanjaard E, Post A, Vliem MJ, Kristyanto H, Bos JL, de RJ (2012) Rap1 can bypass the FAK-Src-paxillin cascade to induce cell spreading and focal adhesion formation. PLoS One 7(11): e50072.

Rozen S, Skaletsky H (2000) Primer3 on the WWW for general users and for biologist programmers. Methods Mol Biol 132: 365-386.

Ruediger R, Pham HT, Walter G (2001) Alterations in protein phosphatase 2A subunit interaction in human carcinomas of the lung and colon with mutations in the A beta subunit gene. Oncogene 20(15): 1892-1899.

Ruediger R, Ruiz J, Walter G (2011) Human cancer-associated mutations in the Aalpha subunit of protein phosphatase $2 \mathrm{~A}$ increase lung cancer incidence in Aalpha knock-in and knockout mice. Mol Cell Biol 31(18): 3832-3844.

Sablina AA, Chen W, Arroyo JD, Corral L, Hector M, Bulmer SE, DeCaprio JA, Hahn WC (2007) The tumor suppressor PP2A Abeta regulates the RalA GTPase. Cell 129(5): 969-982.

Sablina AA, Hector M, Colpaert N, Hahn WC (2010) Identification of PP2A complexes and pathways involved in cell transformation. Cancer Res 70(24): 10474-10484.

Seeling JM, Miller JR, Gil R, Moon RT, White R, Virshup DM (1999) Regulation of beta-catenin signaling by the B56 subunit of protein phosphatase 2A. Science 283(5410): 2089-2091.

Senapati S, Rachagani S, Chaudhary K, Johansson SL, Singh RK, Batra SK (2010) Overexpression of macrophage inhibitory cytokine-1 induces metastasis of human prostate cancer cells through the FAK-RhoA signaling pathway. Oncogene 29(9): 1293-1302.

Sharifi N, Gulley JL, Dahut WL (2005) Androgen deprivation therapy for prostate cancer. JAMA 294(2): 238-244.
Shi Y (2009) Serine/threonine phosphatases: mechanism through structure. Cell 139(3): 468-484.

Siegel R, Naishadham D, Jemal A (2012) Cancer statistics, 2012. CA Cancer J Clin 62(1): 10-29.

Singh AP, Bafna S, Chaudhary K, Venkatraman G, Smith L, Eudy JD, Johansson SL, Lin MF, Batra SK (2008) Genome-wide expression profiling reveals transcriptomic variation and perturbed gene networks in androgen-dependent and androgen-independent prostate cancer cells. Cancer Lett 259(1): 28-38.

Slack JK, Adams RB, Rovin JD, Bissonette EA, Stoker CE, Parsons JT (2001) Alterations in the focal adhesion kinase/Src signal transduction pathway correlate with increased migratory capacity of prostate carcinoma cells. Oncogene 20(10): 1152-1163.

Stephenson RA, Dinney CP, Gohji K, Ordonez NG, Killion JJ, Fidler IJ (1992) Metastatic model for human prostate cancer using orthotopic implantation in nude mice. J Natl Cancer Inst 84(12): 951-957.

Suzuki K, Takahashi K (2003) Reduced expression of the regulatory A subunit of serine/threonine protein phosphatase $2 \mathrm{~A}$ in human breast cancer MCF-7 cells. Int J Oncol 23(5): 1263-1268.

Takagi Y, Futamura M, Yamaguchi K, Aoki S, Takahashi T, Saji S (2000) Alterations of the PPP2R1B gene located at 11q23 in human colorectal cancers. Gut 47(2): 268-271.

Tamaki M, Goi T, Hirono Y, Katayama K, Yamaguchi A (2004) PPP2R1B gene alterations inhibit interaction of PP2A-Abeta and PP2A-C proteins in colorectal cancers. Oncol Rep 11(3): 655-659.

Van Kanegan MJ, Adams DG, Wadzinski BE, Strack S (2005) Distinct protein phosphatase $2 \mathrm{~A}$ heterotrimers modulate growth factor signaling to extracellular signal-regulated kinases and Akt. J Biol Chem 280(43): 36029-36036.

Virshup DM, Shenolikar S (2009) From promiscuity to precision: protein phosphatases get a makeover. Mol Cell 33(5): 537-545.

Wang SS, Esplin ED, Li JL, Huang L, Gazdar A, Minna J, Evans GA (1998) Alterations of the PPP2R1B gene in human lung and colon cancer. Science 282(5387): 284-287.

Wera S, Hemmings BA (1995) Serine/threonine protein phosphatases. Biochem J 311: 17-29.

Westermarck J, Hahn WC (2008) Multiple pathways regulated by the tumor suppressor PP2A in transformation. Trends Mol Med 14(4): $152-160$.

Xu Y, Xing Y, Chen Y, Chao Y, Lin Z, Fan E, Yu JW, Strack S, Jeffrey PD, Shi $\mathrm{Y}$ (2006) Structure of the protein phosphatase 2A holoenzyme. Cell 127(6): 1239-1251.

Yang J, Phiel C (2010) Functions of B56-containing PP2As in major developmental and cancer signaling pathways. Life Sci 87(23-26): 659-666.

Yang J, Wu J, Tan C, Klein PS (2003) PP2A:B56epsilon is required for Wnt/ beta-catenin signaling during embryonic development. Development 130(23): 5569-5578.

Young MR, Kolesiak K, Meisinger J (2002) Protein phosphatase-2A regulates endothelial cell motility and both the phosphorylation and the stability of focal adhesion complexes. Int J Cancer 100(3): 276-282.

Young MR, Liu SW, Meisinger J (2003) Protein phosphatase-2A restricts migration of Lewis lung carcinoma cells by modulating the phosphorylation of focal adhesion proteins. Int J Cancer 103(1): 38-44.

Zhang Q, Claret FX (2012) Phosphatases: the new brakes for cancer development? Enzyme Res 2012: 659649.

This work is published under the standard license to publish agreement. After 12 months the work will become freely available and the license terms will switch to a Creative Commons AttributionNonCommercial-Share Alike 3.0 Unported License.

Supplementary Information accompanies this paper on British Journal of Cancer website (http://www.nature.com/bjc) 